\title{
6 Does a 'LiVing lab' Change it all? About interethnic ENCOUNTERS IN SUPER-DIVERSE NEIGHBOURHOODS IN VIENNA ${ }^{17}$
}

\subsection{Living Labs as co-created spaces of encounter}

Increasing super-diversity makes policymakers recognise the need to provide services for diversifying communities (VERTOVEC 2007). The availability, design and accessibility of local spaces of encounter influences how interethnic encounters take place in super-diverse neighbourhoods. In this light, the study this paper is based on responds to a call for research that analyses 'key forms of space and contact that might yield positive benefits' (VerTOVEC 2007, p. 1046).

Considering different institutionalised and non-institutionalised spaces of encounter, recently, the concept of 'living labs' can be found in social science research designs; they represent a constructed institutionalised space of encounter where local residents, stakeholders and researchers interact. Living labs as 'co-created spaces of encounter' have become popular as a means for achieving more collaborative forms of encounters between a defined set of actors. Since around 2005, living labs have become a well-established tool not only in product development, but also in technological innovation and urban research. Today, living labs are being increasingly included in research programmes to connect research to public and private stakeholders with citizens in order to co-create and co-design products and services to improve living quality in cities (EDWARDS-Schachter et. al. 2012; PASCU and VAN LiEshout 2009). Living labs not only allow explorative and experimental approaches to analysing complex (daily-life) realities; the benefits are also user integration and the use of results in developing needbased products and services that can be implemented into a citizen's living environment in a co-creative manner (Franz 2015). Urban living labs can include (FrANZ et alii 2015, p. 48) a range of topics such as societal, political and technological questions, requiring contextualised approaches in design and implementation of urban living labs.

In this analysis on interethnic coexistence, we develop a framework for a social urban living lab with distinct elements of co-creation. To identify differences between (non-)institutionalised spaces of encounters and urban living labs, we understand cocreation as a collaborative new outcome between two or more groups of actors that include citizens as a prerequisite. Co-creation is based on an explorative environment. Therefore, as many projects in urban research show, it is not possible to foresee whether a specific phase of co-creation can be achieved and maintained. Living labs can, however, be designed to accompany co-creation.

17 This text is based on a conference paper by Julia DAHLVIK \& Yvonne Franz presented at the IMISCOE Conference 2017 in Rotterdam. The authors would like to thank Myrte HoEKSTRA for previous conceptual thoughts and feedback. 
In this article, we compare the effects of living labs and ('unplanned') spaces of encounter on interethnic encounters. The analysis is based on qualitative data (semi-structured interviews and participant observation) from three urban living labs in Vienna: a Neighbourhood Centre, an open community room called 'Herbststraße 15 ', and a community garden called 'Matzner Garden'. All three examples existed as spaces of encounter in the neighbourhood before our research on interethnic coexistence began. They became spaces for research purposes after their potential and existing encounters was identified by researchers, participants and other public stakeholders. This contribution investigates if and how interethnic encounters differ in assigned urban living labs from those in other (non-)institutionalised spaces and what consequences that has for citizens and policy makers.

\subsection{The attempt to create a methodology for urban living labs}

This paper focuses on interethnic coexistence in three distinct neighbourhoods in Vienna. The main aim is to identify the effects on neighbourhood identity and coresponsibility through participation in local integration policies such as bottom-up initiatives or top-down policy measures, for instance, free pre-school. This paper will describe a socially-centred approach to implementing living labs developed due to a lack of existing living lab concepts focusing on socio-spatial research questions (FrANZ et alii 2015 , p. 51). We use the concept of a "space of encounter", to mean places accessed by researchers where local residents already meet and interact with each other, for instance community centres or public spaces. "The "space of encounter" depends in each city on the local conditions, such as access to migrant groups and collaboration with local stakeholders that serve as door-openers to residents" (FrANZ et alii 2015, p. 51).

As for the level of involvement, the authors of this handbook were able to participate in the urban living labs as spaces of encounter, collaborate with stakeholders and engage with affected residents over a longer period and based on trust-building activities. As a result, openness to informal conversations and formalised semi-structured interviews with ethnically diverse residents seemed more likely compared to similar research designs that do not allow for long-term interaction between researchers and (non-) participants. The methodological design allows for the co-creation of more need-based policies between researchers, local residents and local stakeholders.

For reasons of comparability, all urban living labs include established methods, for instance, a comparison of existing statistics, a common evaluation matrix for local policy measures and a questionnaire that can be used a guide when interviewing (non-) participants in local measures. These qualitative interviews are used to engage local residents and gain a more in-depth understanding of interethnic coexistence in the respective neighbourhood. 


\subsection{Implementing Living Labs in Vienna: Local Context of the case studies}

Vienna has currently a total population of $1,797,337$ residents, of whom $25 \%$ do not hold the Austrian citizenship. The current percentage of people with a migration background in Vienna is $36.8 \%$, of which roughly one quarter belongs to the second generation. Since the second half of the $20^{\text {th }}$ century, there has been a constant increase in the proportion of non-citizens in Vienna, reaching a peak in the most recent figures from 2015. 460,163 foreign citizens were legal residents in the Austrian capital, amounting to $25.6 \%$ of the total population. More than $80 \%$ of all foreign nationals living in Vienna come from European countries (if Turkey is included). Immigrants from Turkey and former Yugoslavia are still the most prominent groups of immigrants in Vienna. In terms of urban residential patterns, a fringe of statistical areas around the city centre and expanding into the old working-class districts is characterised by a population which was born in a foreign country representing more than $36 \%$ of the local population in $2014 .^{18}$

Since the founding of the Office for Integration Affairs in 1996, diversity policy has been essential in Vienna. The City of Vienna's integration policies have been aimed at achieving equal rights and opportunities in all areas of life: social, economic, cultural and political. The substantial change within the city and its administrative bodies was that integration was no longer perceived to be an achievement to be accomplished by immigrants, but rather as a process that includes immigrants as well as the members and institutions of the Viennese "host society". The City of Vienna explicitly formulated the growing ethnic diversity and pluralism as an opportunity, rather than a challenge. The previous city concept of "integration" was changed from a deficit-oriented approach into a discourse on integration and diversity that should emphasise the potentials of ethnic diversity and pluralism. The Municipal Department 17 (MA 17) for Integration and Diversity Affairs - founded in 2004 - develops integration and diversity measures further and assists the municipality in mainstreaming and adjusting its services to the needs of Vienna's increasingly diverse population.

For the comparative analysis in this article, three place-based (as opposed to groupbased) initiatives were selected. The Neighbourhood Centre is an institutionalised citywide measure available in several districts, whereas the community centre Herbststraße 15 can be considered semi-institutionalised, as it is only a temporary institution in the study area in the $16^{\text {th }}$ district. In contrast, Matzner Garden, a bottom-up initiative in the $14^{\text {th }}$ district, is understood as an urban living lab due to active contributions by the research team.

\footnotetext{
18 For sources and more details, see the ICEC Baseline Study on Vienna: www.icecproject.com
} 


\subsubsection{The Neighbourhood Centre}

The Neighbourhood Centre is a top-down initiative developed as a low-threshold meeting point in the neighbourhood for people from all social groups and levels of education. It generally has a low threshold and a shop-like walk-in premise. The centre is used both for classes (creative, language, etc.) and open events such as flea markets as well as for activities of certain (closed) groups. The classes mainly attract pensioners and people in difficult (psychological) life situations; this may also be related to the fact that classes take place primarily during the day, when many people have to work. In addition, social counselling is especially appealing to clientele with migration background. Activities for young people were not ver successful, possibly due to a youth centre located near the neighbourhood centre. The mostly Austrian ethnic participants use the donation-based classes for day-structuring purposes as well as to be more active and meet other participants. The regularity of the activities provides a basis for more in-depth contacts among participants.

Promoting the coexistence of the population living in the neighbourhood is one of the basic motivations and an explicit aim of the centre, although some activities have also failed in the past. For instance, the "Activity Stock Market" which tried to bring together people who offered certain talents and others who were searching for such offers. According to the head of the centre, this initiative failed because people were hesitant to leave their private phone numbers to unknown persons. Hence, a certain degree of anonymity is preferred by many (potential) participants of initiatives.

Overall, Austrian participants still make up the majority. The centre is aware of this fact and consciously tries to promote the number of interethnic activities and the participation of migrants. The centre also actively tries to attract specific groups with a migration background. For example, Muslim women from the Islamic Centre were invited to participate in an autumn festival with the effect that a considerable number of women came to the event. The head of the centre, however, regrets that these contacts are often rather short-term. As so often is the case, the language barrier was mentioned as a key problem in this context. In summary, the Neighbourhood Centre also contributes both to inter- and intra-ethnic contacts through the open character of its classes and the availability of rooms for rent for diverse group meetings, for example religious or selfhelp groups, with people from the neighbourhood but also from further away.

\subsubsection{Community room "Herbststraße 15"}

The community room 'Herbststraße $15^{\text {' }}$ is a hybrid initiative in the $16^{\text {th }}$ district, combining top-down and bottom-up elements, which aims to unite people from the adjacent neighbourhood to create something together. It offers a teaching and learning space, space for activities such as sewing or cooking as well as the provision of social and rent advice and language lessons. In the sewing course, for example, women of 
different ethnic backgrounds (mainly Muslim women with Turkish language skills) got together. The initiative offered them a space to meet other women outside of their home, talk, make friends, but also learn something new - more or less independent of their German language skills. The loan shop, on the other hand, which is regularly open on Tuesdays mostly attracted a certain clientele of native young and well-educated people, mostly students, but usually not living in the closer area. It seemed that migrants were not accustomed to this kind of borrowing and were rather hesitant to make use of this offer although the organisers made a particular effort to advertise it. Another activity provided in the community room was rent consultancy. As a research team we were present to observe participation in all those activities and to conduct interviews with participants. However, many did not want to be interviewed for different reasons, such as lack of time, language barriers, or lack of interest in questions concerning the neighbourhood and coexistence of ethnic groups, often due to the own problematic life situation.

Certain activities of the community room also served as an urban living lab with an empowering effect for the participants. This refers particularly to the sewing course in Herbststraße 15 that empowers participants with regard to knowledge about their living environment and labour market access. For example, common visits to city centre and city landmarks were not intended in the first phase of the living lab design. These sideprojects developed over time and created a sense of identification and pride amongst female participants being able to attend an excursion like this. Also, simple knowledge exchange about where to find affordable tutoring courses for children supports female participants in empowering their children to gain a successful education. Finally, the continued participation in the sewing course created an awareness of being able to provide sewing services and self-designed clothes to external buyers. The urban living lab in Herbststraße offers the space for these questions relating to empowerment and contributes to a "space of encounter" that becomes even more considerable to participants.

\subsubsection{Urban Living Lab: Matzner Garden}

Matzner Garden is a bottom-up initiative in the $14^{\text {th }}$ district that was established in the summer of 2015 by the members of the association "Matznergarten - gemeinsam wachsen" (growing together) which was founded for the purpose of the garden. This neighbourhood garden is located at one of the entries of a public park (Matznerpark). The initiative regards this place as a neighbourhood garden, which is also understood as a common place to promote informal learning and participatory engagement with the environment. The possibility to plant fruits and vegetables is only seen as one aspect of the garden. Intercultural exchange and the focus on togetherness are intended to counteract the anonymity of the big city.

In the beginning particularly, it was primarily Austrian middle class residents who were engaged in this initiative with a common goal. Non-Austrians did often 
not feel addressed or included in the measure although that was explicitly intended as participants. The initiative itself has drawn attention in the neighbourhood after building raised beds together with members of the associations and mostly children from the adjacent environment. The general opinion on the community garden is positive amongst respondents from the neighbourhood. The initiative is particularly appreciated for its work with children who may get in contact with and learn from nature. In addition, it is assumed that German language skills can be improved as a side-effect.

However, critical opinions have also been identified, specifically access to information on the garden and how to rent a raised bed seemed to be difficult for interested persons. This creates an exclusionary effect as some interviewees mentioned that they did not feel welcome in the community garden. Consequently, the garden does not only need to provide an inviting environment with an open and welcoming physical structure, but also information about how to participate in future events. The aspect of vibrancy and events in the community garden, however, should not be underestimated as it provides an "opening" moment for the neighbourhood. Those respondents who know the Matzner Garden, but do not participate, refer mainly to time constraints and non-interest in garden-related activities. Both seem to be of importance when it comes to the assessment of integrative mechanisms through gardening. Despite the positive reputation of community gardens as an integrative measure, there are practical components in individuals' realities which limit the effectiveness of participation, such as time and interest.

The Urban Renewal Office played an important role in bringing together the different actors. With its contact to these residents, the office was able to connect a group of people interested in creating a neighbourhood garden and support them in implementing their idea. The association that was founded by the group is non-profit and financed through membership fees, donations, public (municipality, district leader) and private sponsorships. As an urban living lab, the initiative was also co-sponsored by the research project and influenced - through providing workshops - the involvement of the ethnically diverse population in the neighbourhood too. The garden is designed to be a location for diverse events - workshops, activities, possibilities for social and cultural encounter - throughout the year. The research team was actively involved in several of these activities, which allowed for a process of collaboration and co-creation with citizens and researchers.

\subsection{Comparative conclusion: Consequences for citizens and policymakers}

The success of an initiative is mainly linked to the numbers of participants, continuity and - in our study design - the degree of interethnic coexistence. The type and design of a measure, including its embeddedness within governance structures, influence 
who participates, why and to what effect. Defining characteristics include top-down, bottom-up and hybrid as well as group or place-based constellations of initiatives. In addition, we can distinguish measures that are free as opposed to those with a fixed-fee or donation-based. While some initiatives require German language skills, they are less relevant in others. Only a few initiatives manage to achieve a relatively balanced mix of Austrian and non-Austrian participants. The reasons and motivations for participation voluntary versus required - have to be taken into consideration as well as those for nonparticipation, such as time pressures and/or financial limitations, lack of interest, lack of knowledge of the initiative or other measure-specific reasons (e.g. not feeling welcome, a certain language barrier).

The research project revealed that initiatives have not only inclusionary, but also exclusionary effects. Both formal (e.g. language or employment requirements) and informal exclusion (e.g. social composition of organisers or a certain ethnic dominance) mechanisms can produce barriers to participation. Ethnic and socioeconomic differences as well as an individual's ability and motivation to participate will influence the 'mixture' of participants. We found that education and employment play an important role in this context: it is typically easier for more highly educated people to organise an initiative; while those not (regularly) employed have more time to participate, they sometimes see participation as a barrier to finding a job rather than as a possible step towards labour market integration. Still, the initiative's design and specific offers affect whether residents are interested and willing to invest time and energy (see HoEKSTRA \& DAHLVIK 2017). It is thus important to consider the inclusiveness or exclusiveness of measures, based on differentiated needs of target groups.

Comparing institutionalised and top-down initiatives to less institutionalised bottom-up initiatives, we find that while the former contribute to connecting participants to educational and housing institutions, they rarely enable the creation of strong relationships among residents. In contrast, bottom-up, less institutionalised initiatives better enable low-threshold social contacts, including to representatives of Austrian mainstream society (ibid). Hence, organisers and local institutional actors need to consider how the structure of their initiative influences who takes part; different incentives need to be employed to 'give a voice' to social groups who currently do not feel addressed by, nor interested in, existing initiatives.

The degree of institutionalisation also affects whether an initiative can create a sense of belonging and promote place attachment, social embeddedness and coresponsibility. While self-organised groups can be exclusionary (e.g., including mainly highly educated Austrians), the organisers of top-down measures argue they are able to actively steer the inclusion of non-Austrian ethnic persons. On the other hand, the study shows that bottom-up initiatives are more likely to create co-ownership and coresponsibility, which may also be a prerequisite for participation.

This article also highlighted the difference between (non-)institutionalised spaces of encounters and urban living labs. The latter has the potential to create more 
interethnic encounters as long as a truly co-creative setting between initiators, residents and researchers can be assured. Co-creation is the potential outcome of interethnic encounters that requires the openness of the initiators to including the needs and interests researchers addressing a specific research question. In this case, research can also act as a certain corrective for integration policies that aim to promote inclusion, but fall victim to unintended exclusionary mechanisms.

\section{ZUSAMMENFASSUNG:}

Das letzte vorliegende Kapitel widmet sich einer speziellen, aber dafür umso innovativeren Thematik. Es werden, ausgehend von der seit Mitte der 2000er-Jahre auch die Sozialwissenschaften stimulierenden Living-Lab-Konzeption, die Effekte von Urban Living Labs und ", ungeplanter" Begegnungsräume auf interethnische Kontakte untersucht. Die Analyse basiert methodisch auf halbstrukturierten Interviews und teilnehmenden Beobachtungen in drei Urban Living Labs in Wien, nämlich dem Nachbarschaftszentrum in Gumpendorf, dem Nachbarschaftsraum „Herbststraße 15“ sowie dem Urban-Gardening-Projekt „, Matznergarten “im 14. Wiener Gemeindebezirk. Es wird untersucht, ob und in welcher Weise sich interethnische Begegnungen in den drei Living Labs unterscheiden von anderen institutionalisierten Räumen und welche Konsequenzen dies für die BewohnerInnen und die politischen Entscheidungsträger hat. In der vorliegenden Untersuchung bildete eine Konzeption des Social Urban Living Labs mit ausgeprägten Elementen der Kokreation, die auf einem explorativen Umfeld basiert, den Ansatzpunkt. Die komparative Analyse zeigt, dass der Erfolg einer Initiative vor allem abhängt von der Zahl ihrer TeilnehmerInnen, ihrer Kontinuität und dem Grad interethnischer Begegnung. Nur in relativ wenigen Initiativen kann wirklich eine Durchmischung von nichtösterreichischen und österreichischen TeilnehmerInnen beobachtet werden. Dies hängt mit inkludierenden beziehungsweise exkludierenden Effekten der untersuchten Maßnahmen zusammen, wobei die Ausschließungsmechanismen keineswegs nur ethnisch, sondern auch sozioökonomisch zu verstehen sind. Als Ergebnis ist festzuhalten, dass Kontext und Design einer Initiative sowie deren Grad der Institutionalisierung die Art der Begegnung und somit auch die Erfahrungen der BewohnerInnen mit ihrem Wohnumfeld beeinflussen. TeilnehmerInnen an Initiativen versuchen häufig, eine Balance zu finden zwischen Behaglichkeit und Informalität einerseits sowie Inklusivität und Offenheit andererseits. Es ist daher möglich, dass ein und dieselbe Initiative bei unterschiedlichen Personen sowohl ein Gefühl der Zugehörigkeit als auch Gefühle der Exklusion erzeugt.

Die Resultate der vergleichenden Untersuchung zeigen, dass TeilnehmerInnen nicht notwendigerweise auf der Suche nach sehr engen Sozialkontakten sind. Es ist daher wichtig, die Rolle fließender und unverbindlicher sozialer Interaktionen hervorzuheben und diese entsprechend zu fördern. BewohnerInnen bevorzugen häufig oberflächliche Begegnungen und die persönlichen Motivationen für die Teilnahme an Initiativen finden sich nicht selten in dem Versuch, persönliche Lebensumstände zu 
verbessern. Differenzierte Bedürfnisse von Zielgruppen sind vor allem hinsichtlich der Inklusivität bzw. Exklusivität von Maßnahmen und Aktivitäten zu berücksichtigen, wobei der Typus von Initiativen ebenfalls eine erhebliche Rolle spielt. Bottom-up-Initativen sind eher geeignet Mitverantwortlichkeit und letztlich lokale Teilhabe zu fördern. Urban Living Labs sind in der Lage mehr interethnische Sozialkontakte zu fördern, solange kokreative Settings von Rahmenbedingungen zwischen InitiatorInnen, BewohnerInnen und ForscherInnen gewährleistet sind. Kokreation ist ein wichtiges Ergebnis interethnischer Begegnungen in Living Labs, welches die Offenheit der InitiatorInnen voraussetzt, die Bedüfnisse und Forschungsinteressen entsprechend einzubinden und aufeinander abzustimmen. In diesem Fall kann Forschung also auch als ein Korrektiv für Integrationspolitiken dienen, welche eigentlich auf Inklusion gerichtet sind, jedoch unintendierte Exklusionsmechanismen beinhalten.

\section{SAMENVATTING:}

Vanaf midden jaren 2000 wordt binnen de sociale wetenschappen al onderzoek gedaan naar de effecten van zogeheten 'Urban Living Labs' en ongeplande ontmoetingsruimtes op interetnische contacten. De analyse in dit hoofdstuk is gebaseerd op semigestructureerde interviews en participerende observatie in drie 'Urban Living Labs' in Wenen, te weten het buurthuis in Gumpendorf, de openbare gemeenschapsruimte "Herbststraße 15" en het stadstuinierproject "Matznergarten" in het $14^{e}$ district. Onderzocht is of, en zoja op welke manier, interetnische contacten in deze drie Living Labs zich onderscheiden van contacten in meer geïnstitutionaliseerde ruimtes en welke gevolgen dit heeft voor de buurtbewoners en de stadsdeelbestuurders. In dit onderzoek staat een concept van Urban Living Labs centraal waarbij co-creatie van bewoners het uitgangspunt is. De vergelijkende analyse laat zien dat het succes van een initiatief afhangt van het aantal deelnemers, de duur van hun betrokkenheid en de mate van interetnische contacten. In maar weinig initiatieven kan worden gesproken van een daadwerkelijke mix tussen Oostenrijkse en niet-Oostenrijkse deelnemers. Dit heeft te maken met de insluitende dan wel uitsluitende mechanismen van de onderzochte initiatieven, waarbij bij uitsluitende mechanismen niet alleen moet worden gedacht aan uitsluiting van etnische anderen, maar ook aan uitsluiting op sociaaleconomische grond. Context en ontwerp van het initiatief, evenals de mate van institutionalisering beïnloeden de vorm en mate van contacten binnen het initiatief en daarmee ook - in bredere zin - hoe bewoners hun buurt ervaren. Organisators van initiatieven proberen vaak een goede balans te vinden tussen enerzijds het creëren van een gezellige en informele setting, en anderzijds open en inclusief zijn. Dit is echter lastig te realiseren en hierdoor kan het voorkomen dat hetzelfde initiatief bij sommige deelnemers een gevoel van saamhorigheid en eenheid oproept, terwijl anderen zich buitengesloten voelen.

Het vergelijkende onderzoekt toont aan dat deelnemers niet noodzakelijkerwijs op zoek zijn naar hechte sociale contacten. Het is daarom belangrijk dat meer vluchtige, oppervlakkige sociale contacten ook worden gezien als waardevol en dat beleid zich 
er ook op richt deze te bevorderen. Bewoners hebben vaak liever meer oppervlakkige contacten, en hun deelname aan een initiatief komt niet zelden voort uit andere motieven zoals de wens hun persoonlijke omstandigheden te verbeteren (in plaats van het opdoen van meer sociale contacten). Ook is het belangrijk rekening te houden met de behoeftes van verschillende doelgroepen. Het gaat hier met name om het voorkomen van uitsluitende mechanismen, waarbij ook de aard van de initiatieven een belangrijke factor is. Bottom-up initiatieven zijn vaak beter gepositioneerd om medeverantwoordelijkheid en uiteindelijk lokale participatie te bevorderen. Urban Living Labs kunnen zorgen voor meer interetnische contacten, maar hiervoor moet de creatieve samenwerking tussen bewoners, initiatiefnemers en onderzoekers wel worden gewaarborgd. Co-creatie is een belangrijk maar lastig te realiseren gevolg van interetnische contacten in Living Labs. Vereist hiervoor is een goede coördinatie van de behoeften en interesses van verschillende groepen, waaronder ook de onderzoekers. Op deze manier kan onderzoek ook worden gezien als correctie op integratiebeleid dat weliswaar gericht is op inclusie, maar onbedoeld ook uitsluitende mechanismen genereert. 